\title{
AN INTERVAL FINITE DIFFERENCE METHOD FOR THE BIOHEAT TRANSFER PROBLEM DESCRIBED BY THE PENNES EQUATION WITH UNCERTAIN PARAMETERS
}

\begin{abstract}
SUMMARY
In this paper the transient bioheat transfer problem given by the one-dimensional Pennes equation with mixed boundary conditions is considered. The model assumes the heat transfer between the skin and its surroundings in the case of a natural and forced convection. For computations the interval finite difference method of Crank-Nicolson type together with the floating-point interval arithmetic is used. In this way, uncertain geometric and thermophysical parameters can be represented in the form of intervals as well as the resultant temperature distribution over time.
\end{abstract}

Keywords: bioheat transfer modelling, interval finite difference method, Pennes equation

PRZEDZIAEOWA METODA RÓŻNIC SKOŃCZONYCH W ZAGADNIENIU PRZEPŁYWU BIOCIEPŁA OPISANYM ROWNANIEM PENNESA ZALEZNY

$W$ pracy rozważa się nieustalone zagadnienie przeptywu biociepta $w$ skórze opisane równaniem Pennesa z mieszanymi warunkami brzegowymi. W modelu uwzględniono wymianę ciepła między skóra a otoczeniem zarówno w przypadku konwekcji swobodnej, jak i wymuszonej. Do obliczeń wykorzystano przedzialowa metodę różnic skończonych typu Cranka-Nicolsona oraz zmiennopozycyjnq arytmetykę przedziatowa. $W$ ten sposób nieprecyzyjnie określone wartości parametrów geometrycznych i termofizycznych moga być reprezentowane $w$ postaci przedziatów, podobnie jak wynikowy rozklad temperatury w czasie.

Stowa kluczowe: modelowanie przeplywu biociepła, przedziatowa metoda różnic skończonych, równanie Pennesa

\section{INTRODUCTION}

The concept of interval arithmetic and interval methods was first introduced by Sunaga (Sunaga 1958) and Moore (Moore 1966). It provides a useful tool for results verification. Interval solutions obtained by interval methods include the exact solution of the problem considered. Moreover, computer implementation of the interval methods in the floating-point interval arithmetic (Moore 1966; Jankowska 2006, 2010; Marciniak 2009), together with the representation of the initial data in the form of machine intervals, allows us achieve interval solutions that contain all possible numerical errors. An interval and fuzzy set approach to initial-boundary value problems with uncertain parameters is also under development. If we focus on the Polish research contribution we can point out the following selected solutions: Burczyński, Skrzypczyk (Burczyński and Skrzypczyk 1997) Zieniuk, Kużelewski (Kużelewski 2008; Zieniuk 2000), Piasecka-Belkhayat (Piasecka-Belkhayat 2011), Marciniak, Jankowska, Szyszka (Jankowska 2010, 2012, 2013; Jankowska and Marciniak; Jankowska et al. 2012; Marciniak 2012; Szyszka 2012).

A variety of different boundary-value problems of the bioheat transfer in soft tissues, with particular reference to skin, are studied and solved with the boundary element method in e.g. (Majchrzak et al. 2008; Majchrzak and Jasiński
2003; Majchrzak et al. 2005). In the paper the interval finite difference method of Crank-Nicolson type for solving the heat conduction problem given by the heat conduction equation with heat sources linearly depending on the unknown function is used (Jankowska and Sypniewska-Kamińska 2013). It is applied for solving the bioheat transfer problem with the Pennes equation (Będziński 2011; Pennes 1948; Xu et al. 2008) and mixed boundary conditions. We assume the heat conduction in the skin which consists of three layers, i.e. epidermis, dermis and subcutaneous tissue. The heat transfer between the skin and its surroundings is due to a natural and forced convection. Since computations are performed in the floating-point interval arithmetic, then some parameters such as a thickness of skin and thermophysical properties of skin and blood, can be represented in the form of intervals. Such intervals let us take into consideration the measurement uncertainties that can arise during the physical experiments and also a variety of values that can be taken by parameters as the effect of some environmental factors, i.e. age, state of health, lifestyle etc. The interval solutions obtained include all values that can be taken by parameters occurring in the problem formulation, as well as the error of the conventional method and the errors caused by the floating-point arithmetic used by computers, i.e. rounding errors and representation errors.

* Institute of Applied Mechanics, Poznan University of Technology, Poznan, Poland; e-mail: malgorzata.jankowska@put.poznan.pl, grazyna.sypniewska-kaminska@put.poznan.pl 


\section{INTERVAL FINITE DIFFERENCE METHOD OF CRANK-NICOLSON TYPE}

The interval method of Crank-Nicolson type for solving the one-dimensional heat conduction equation with the boundary conditions of the first kind were proposed by Marciniak in (Marciniak 2012). Jankowska extended his work taking into account the same equation with the mixed boundary conditions (Jankowska 2012). The interval method proposed enables to include in the interval solutions obtained the local truncation error of the conventional method which is normally neglected. For the interval method (Jankowska 2012) we can show that the exact solution of the problem belongs to the interval solutions obtained. Note that in practice it is not easy to satisfy all the assumptions made in the theoretical formulation of the method given in (Jankowska 2012). Nevertheless, the appropriate techniques for the approximation of end-points of the error term intervals in each step of the method are described in (Jankowska 2013). Numerical tests performed by the author confirmed their effectiveness and usefulness. Nevertheless, we cannot formally guarantee that the exact solution belongs to the appropriate interval solutions obtained with the error term approximation considered.

The interval finite difference method presented in (Jankowska and Sypniewska-Kamińska 2013) is based on the interval method of Crank-Nicolson type (ICN method) proposed in (Jankowska 2012, 2013). It concerns the heat conduction equation with the heat sources, given by a function that is linear with respect to the unknown temperature (ICN-LHS method) and the initial-boundary conditions of the form

$$
\begin{aligned}
& \frac{\partial u}{\partial t}(x, t)-\alpha^{2} \frac{\partial^{2} u}{\partial x^{2}}(x, t)= \\
& =\alpha_{1}+\alpha_{2} u(x, t), \quad 0<x<L, t>0 \\
& u(x, 0)=f(x), \quad 0 \leq x \leq L, \\
& \frac{\partial u}{\partial x}(0, t)-A u(0, t)=\varphi_{1}(t), \\
& \frac{\partial u}{\partial x}(L, t)+B u(L, t)=\varphi_{2}(t), \quad t>0
\end{aligned}
$$

where $\alpha, \alpha_{1}, \alpha_{2}, A, B$ are constants and their values depend on the physical nature of the problem.

Let us set the maximum time $t_{\max }$ and choose integers $n$ and $m$. We find the mesh constants $h$ and $k$ such as $h=L / n$ and $k=t_{\text {max }} / m$. Hence, the grid points are $\left(x_{i}, t_{j}\right)$, where $x_{i}=i h$ for $i=0,1, \ldots, n$ and $t_{j}=j k$ for $j=0,1, \ldots, m$.

For the interval method values of all coefficients $\alpha, \alpha_{1}$, $\alpha_{2}, A, B, L, t_{\max }$ should be given in the form of appropriate intervals. Then, for the functions $f, \varphi_{1}, \varphi_{2}$, their interval extensions $F, \Phi_{1}, \Phi_{2}$ are created. With the interval function $F$ we have

$$
U_{i, 0}=F\left(X_{i}\right), i=0,1, \ldots, n
$$

where $U_{i, 0}=U\left(x_{i}, t_{0}=0\right)$ and $u\left(x_{i}, t_{0}=0\right) \in U_{i, 0}$. Moreover, $X_{i}, i=0,1, \ldots, n, T_{j}, \mathrm{j}=0,1, \ldots, n$, are intervals such that $x_{i} \in X_{i}, t_{j} \in T_{j}$ and $F=F(X), \Phi_{1}=\Phi_{1}(T), \Phi_{2}=\Phi_{3}(T)$.

The ICN-LHS method (Jankowska and Sypniewska-Kamińska 2013) can be given in the following matrix form

$$
\begin{aligned}
& C U^{(1)}=D^{(0)} U^{(0)}+E_{C}^{(1)}+E_{L}^{(1)}, j=0 \\
& C U^{(j+1)}=D^{(1)} U^{(j)}+E_{C}^{(j+1)}+E_{L}^{(j+1)}, j=1,2, \ldots, m-1
\end{aligned}
$$

where $U^{(j)}=\left[U_{0, j}, U_{1, j}, \ldots, U_{n, j}\right]^{T}, u\left(x_{i}, t_{j}\right) \in U_{i, j}$ and $C$, $D^{(0)}, D^{(1)}$ are matrixes of coefficients and $E_{C}^{(j)}$ are vectors of coefficients. Furthermore, $E_{L}^{(j)}$ are vectors such that a local truncation error of the conventional finite-difference method at each mesh point is enclosed in. If we cannot satisfy all the assumptions required for such a local truncation error inclusion, then we use the appropriate method of approximation of the error term intervals (as described in (Jankowska and Sypniewska-Kamińska 2013)). Despite such approach is not enough to guarantee the inclusion of the local truncation error in the resultant interval solutions, the numerical experiments confirm that the exact solution do belong to the interval solutions obtained.

\section{BIOHEAT TRANSFER PROBLEM GIVEN BY THE PENNES EQUATION}

Consider a three-layer model of skin that consists of epidermis, dermis and subcutaneous tissue of thickness $L_{1}, L_{2}$ and $L_{3}$, respectively (see Fig. 1). Hence, we have $L=L_{1}+L_{2}+L_{3}$.

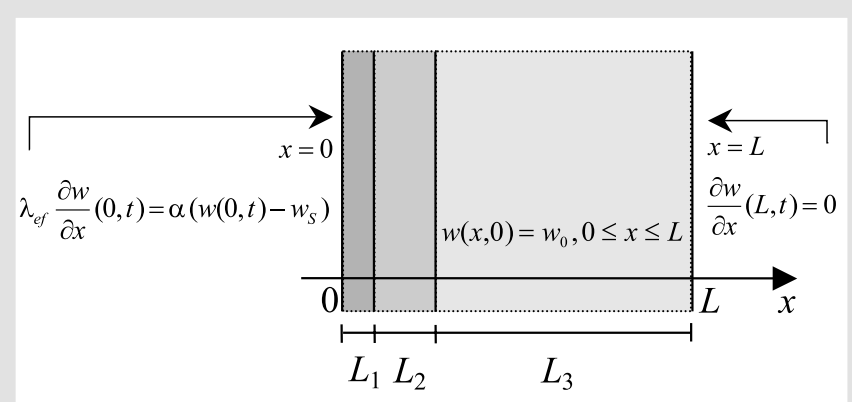

Fig. 1. Three-layer model of skin: epidermis, dermis and subcutaneous tissue with the initial and boundary conditions of the bioheat transfer problem (6)-(8)

The physical properties which are used to describe each layer depend on many different environmental factors, e.g. age, state of health, lifestyle etc. Hence, we usually know only a range of values rather than an exact value that a given parameter can be equal to. The physical pro-perties of skin layers and blood are collected on the basis of available reference materials in Table 1 and Table 2, respectively. 
Table 1

Values of parameters for three-layer model of skin

\begin{tabular}{|c|c|c|c|c|}
\hline Parameters & Skin layer & Range of values & $\begin{array}{l}\text { Mean } \\
\text { Value }\end{array}$ & $\begin{array}{l}\text { References } \\
\text { on ranges of values }\end{array}$ \\
\hline \multirow{4}{*}{$\begin{array}{l}\text { Thickness } \\
L[\mathrm{~m}]\end{array}$} & Epidermis & 7.0E-5 - 1.3E-4 & $1 \mathrm{E}-4$ & $\begin{array}{l}\text { Assumption; see also (Xu et al. } \\
\text { 2008) }\end{array}$ \\
\hline & Dermis (neck) & $1.28 \mathrm{E}-3-1.56 \mathrm{E}-3$ & $1.42 \mathrm{E}-3$ & (Dahan et al. 2004; Xu et al. 2008) \\
\hline & Dermis (forehead) & $1.60 \mathrm{E}-3-1.98 \mathrm{E}-3$ & $1.79 \mathrm{E}-3$ & (Dahan et al. 2004; Xu et al. 2008) \\
\hline & Subcutaneous tissue & 4.0E-3 - $4.8 \mathrm{E}-3$ & 4.4E-3 & $\begin{array}{l}\text { Assumption; see also (Xu et al. } \\
\text { 2008) }\end{array}$ \\
\hline \multirow{3}{*}{$\begin{array}{l}\text { Thermal } \\
\text { conductivity } \\
\lambda[\mathrm{W} /(\mathrm{m} \cdot \mathrm{K})]\end{array}$} & Epidermis & $0.21-0.26$ & 0.235 & (Będziński 2011; Torvi et al. 1994) \\
\hline & Dermis & $0.37-0.52$ & 0.445 & (Będziński 2011; Torvi et al. 1994) \\
\hline & Subcutaneous tissue & $0.16-0.21$ & 0.185 & (Będziński 2011; Torvi et al. 1994) \\
\hline \multirow{3}{*}{$\begin{array}{l}\text { Specific heat } \\
c[\mathrm{~J} /(\mathrm{kg} \cdot \mathrm{K})]\end{array}$} & Epidermis & $3578-3600$ & 3589 & (Będziński 2011; Torvi et al. 1994) \\
\hline & Dermis & $3200-3400$ & 3300 & (Będziński 2011; Torvi et al. 1994) \\
\hline & Subcutaneous tissue & $2288-3060$ & 2674 & (Będziński 2011; Torvi et al. 1994) \\
\hline \multirow{3}{*}{$\begin{array}{l}\text { Mass density } \\
\rho\left[\mathrm{kg} / \mathrm{m}^{3}\right]\end{array}$} & Epidermis & 1190 & 1190 & (Dahan et al. 2004; Duck 1990) \\
\hline & Dermis & 1116 & 1116 & (Dahan et al. 2004; Duck 1990) \\
\hline & Subcutaneous tissue & 971 & 971 & (Dahan et al. 2004; Duck 1990) \\
\hline \multirow{3}{*}{$\begin{array}{l}\text { Metabolic heat } \\
\text { generation } \\
\dot{Q}_{m e t}\left[\mathrm{~W} / \mathrm{m}^{3}\right]\end{array}$} & Epidermis & 0 & 0 & (Będziński 2011) \\
\hline & Dermis (in rest) & 245 & 245 & (Będziński 2011) \\
\hline & $\begin{array}{l}\text { Subcutaneous tissue } \\
\text { (in rest) }\end{array}$ & 245 & 245 & (Będziński 2011) \\
\hline \multirow{3}{*}{$\begin{array}{l}\text { Blood perfusion } \\
\text { rate } \\
G_{B}[1 / \mathrm{s}]\end{array}$} & Epidermis & 0 & 0 & (Będziński 2011) \\
\hline & Dermis & $0-0.00125$ & 0.000625 & (Będziński 2011) \\
\hline & Subcutaneous tissue & $0-0.00125$ & 0.000625 & (Będziński 2011) \\
\hline
\end{tabular}

Table 2

Values of parameters for blood

\begin{tabular}{|l|c|c|l|}
\hline \multicolumn{1}{|c|}{ Parameter } & Range of values & $\begin{array}{c}\text { Mean } \\
\text { Value }\end{array}$ & \multicolumn{1}{c|}{$\begin{array}{c}\text { References } \\
\text { on ranges of values }\end{array}$} \\
\hline Thermal conductivity $\lambda_{B}[\mathrm{~W} /(\mathrm{m} \cdot \mathrm{K})]$ & $0.4-0.5$ & 0.45 & (Będziński 2011) \\
\hline Specific heat $c_{B}[\mathrm{~J} /(\mathrm{kg} \cdot \mathrm{K})]$ & 3770 & 3770 & (Będziński 2011) \\
\hline Mass density $\rho_{B}\left[\mathrm{~kg} / \mathrm{m}^{3}\right]$ & 1060 & 1060 & (Będziński 2011) \\
\hline Temperature of blood in aorta $w_{B}\left[{ }^{\circ} \mathrm{C}\right]$ & 37 & 37 & \\
\cline { 1 - 3 } & & &
\end{tabular}

We introduce effective values of the thermophysical parameters of the skin in the following way: $\lambda_{e f}=\left(\lambda_{1} L_{1}+\lambda_{2} L_{2}+\right.$ $\left.+\lambda_{3} L_{3}\right) / L[\mathrm{~W} /(\mathrm{m} \cdot \mathrm{K})]$ is the effective thermal conductivity, $c_{e f}=\left(c_{1} L_{1}+c_{2} L_{2}+c_{3} L_{3}\right) / L[\mathrm{~J} /(\mathrm{kg} \cdot \mathrm{K})]$ is the effective specific heat and $\rho_{e f}=\left(\rho_{1} L_{1}+\rho_{2} L_{2}+\rho_{3} L_{3}\right) / L\left[\mathrm{~kg} / \mathrm{m}^{3}\right]$ is the effective mass density. We assume that an initial tempera- ture of the skin layers is equal to $w_{0}$. A surrounding air temperature is equal to $w_{S}$ and it is maintained constant over time. On the internal surface that separates the subcutaneous tissue from the body we assume insulation. There is also a heat generation in the skin layers considered. It is due to some metabolic and perfusion heat sources. 
Under the above assumptions, the distribution of temperature is given by a function $w=w(x, t)$ which depends on only one spatial variable $x$. It is described by the one-dimensional Pennes bioheat transfer equation and the initial and boundary conditions of the form

$$
\begin{aligned}
& c_{e f} \rho_{e f} \frac{\partial w}{\partial t}(x, t)-\lambda_{e f} \frac{\partial^{2} w}{\partial x^{2}}(x, t)=\dot{Q}(x, t) \\
& w(x, 0)=w_{0}, \quad 0 \leq x \leq L, \\
& \lambda_{e f} \frac{\partial w}{\partial x}(0, t)=\alpha\left(w(0, t)-w_{S}\right), \quad \frac{\partial w}{\partial x}(L, t)=0, t>0,
\end{aligned}
$$

where $\dot{Q}(x, t)\left[\mathrm{W} / \mathrm{m}^{3}\right]$ is the rate of heat source generation in the skin layers specified per unit volume and $\alpha\left[\mathrm{W} /\left(\mathrm{m}^{2} \cdot \mathrm{K}\right)\right]$ is the convection heat transfer coefficient. We assume that

$$
\dot{Q}(x, t)=\dot{Q}_{m e t, e f}+\dot{Q}_{\text {perf }}(x, t),
$$

where

$$
\begin{aligned}
& \dot{Q}_{m e t, e f}=\left(\dot{Q}_{m e t, 1} L_{1}+\dot{Q}_{m e t, 2} L_{2}+\dot{Q}_{m e t, 3} L_{3}\right) / L, \\
& \dot{Q}_{\text {perf }}(x, t)=G_{B, \text { ef }} c_{B} \rho_{B}\left(w_{B}-w(x, t)\right),
\end{aligned}
$$

$\dot{Q}_{m e t, e f}, \dot{Q}_{\text {perf }}(x, t)\left[\mathrm{W} / \mathrm{m}^{3}\right]$ denote the effective metabolic heat generation in the skin and the perfusion heat generation, respectively, $\mathrm{G}_{B, e f}=\left(\mathrm{G}_{B, 1} L_{1}+\mathrm{G}_{B, 2} L_{2}+\mathrm{G}_{B, 3} L_{3}\right) / L[1 / \mathrm{s}]$ is the effective blood perfusion rate, $c_{\mathrm{B}}[\mathrm{J} /(\mathrm{kg} \cdot \mathrm{K})]$ is the specific heat of blood, $\rho_{B}\left[\mathrm{~kg} / \mathrm{m}^{3}\right]$ is the mass density of blood, $w_{B}[\mathrm{~K}]$ is a temperature of blood in aorta. The effective thermal diffusivity is $\kappa_{e f}=\lambda_{e f} /\left(c_{e f} \rho_{e f}\right)\left[\mathrm{m}^{2} / \mathrm{s}\right]$.

The initial-boundary problem (6)-(8) can be transformed to the non-dimensional form

$$
\begin{aligned}
& \frac{\partial u}{\partial \tau}(\xi, \tau)-\frac{\partial^{2} u}{\partial \xi^{2}}(\xi, \tau)=g_{1}+g_{2} u(\xi, \tau), \\
& u(\xi, 0)=u_{0}, \quad 0 \leq \xi \leq 1, \\
& \frac{\partial u}{\partial \xi}(0, \tau)=\operatorname{Bi} u(0, \tau), \quad \frac{\partial u}{\partial \xi}(1, \tau)=0, \quad \tau>0,
\end{aligned}
$$

a)

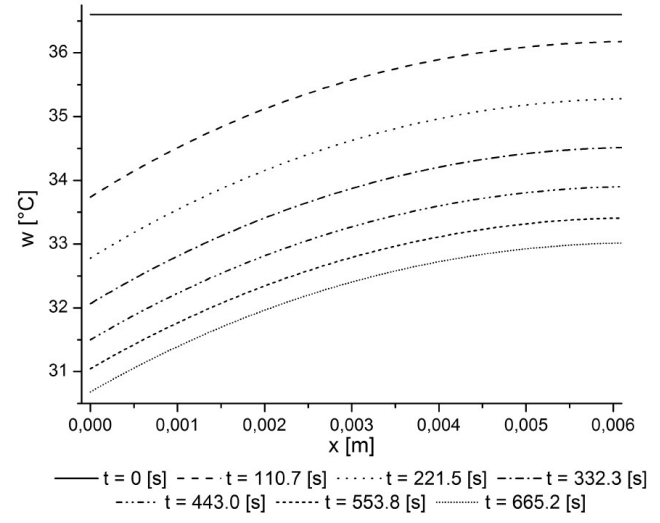

where

$$
g_{1}=\tilde{\dot{Q}}_{m e t, e f}+\tilde{G}_{B, \text { ef }} \tilde{c}_{B} \tilde{\rho}_{B} u_{B}, \quad g_{2}=-\tilde{G}_{B, e f} \tilde{c}_{B} \tilde{\rho}_{B}
$$

and $\xi=x / L, \tau=\kappa_{e f} t / L^{2}, u(\xi, \tau)=\left(w(x(\xi), t(\tau))-w_{\mathrm{S}}\right) / \Delta w$, where $\Delta w=w_{B}-w_{S}$. The Ostrogradsky and Biot numbers are defined by Os $=\tilde{Q}_{m e t, e f}=\left(\dot{Q}_{m e t, e f} L^{2}\right) /\left(\Delta w \lambda_{e f}\right)$, $\mathrm{Bi}=(\alpha L) / \lambda_{e f}$. Moreover, $u_{B}$ denotes the non-dimensional temperature of blood in aorta, $u_{B}=\left(w_{B}-w_{S}\right) / \Delta w=1$, $\tilde{G}_{B, e f}=\left(G_{B, e f} L^{2}\right) / \kappa_{e f}, \tilde{c}_{B}=c_{B} / c_{e f}$ and $\tilde{\rho}_{B}=\rho_{B} / \rho_{e f}$.

For the bioheat transfer model we consider a natural and forced convection. In case of the natural convection we derive the convection heat transfer coefficient $\alpha$ as in (Gdula ed. 1984), (Orzechowski 2001). For the temperature of skin $w_{0}=309.75 \mathrm{~K}\left(36.6{ }^{\circ} \mathrm{C}\right)$ and the surrounding air temperature $w_{S}=273.15 \mathrm{~K}\left(0^{\circ} \mathrm{C}\right)$, we have $\mathrm{Gr} \cdot \mathrm{Pr}=2.71264 \times 10^{6}$, where $\mathrm{Gr}$ is the Grashof number and $\mathrm{Pr}$ is the Prandtl number. The product corresponds to the transitional flow with the Nusselt number $\mathrm{Nu}=0.54(\mathrm{Gr} \cdot \mathrm{Pr})^{1 / 4}$. Then, we have $\alpha=\left(\mathrm{Nu} \cdot \lambda_{p}\right) / l$, where $\lambda_{p}[\mathrm{~W} /(\mathrm{m} \cdot \mathrm{K})]$ is the thermal conductivity of air and $l[\mathrm{~m}]$ is the characteristic dimension of the surface exchanging heat. With $\lambda_{p}=0.0243 \mathrm{~W} /(\mathrm{m} \cdot \mathrm{K})$ at $273.15 \mathrm{~K}\left(0{ }^{\circ} \mathrm{C}\right), l=0.08 \mathrm{~m}$, we get $\alpha \approx 6.66 \mathrm{~W} /\left(\mathrm{m}^{2} \cdot \mathrm{K}\right)$.

In Figure 2 we have the temperature distribution in case of natural convection with $\alpha=6.66 \mathrm{~W} /\left(\mathrm{m}^{2} \cdot \mathrm{K}\right)$ and $w_{0}=309.75 \mathrm{~K}\left(36.6^{\circ} \mathrm{C}\right), w_{S}=273.15 \mathrm{~K}\left(0^{\circ} \mathrm{C}\right)$, where values of physical parameters are equal to mean values given in Tables 1-2, except for the blood perfusion rate $G_{B}$ for dermis and subcutaneous tissue. We take $G_{B, 2}=G_{B, 3}=0.001251 / \mathrm{s}$.

For the forced convection caused by the wind we can use the empirical equation proposed in (Cameron et al. 1999) of the form $\alpha=10.45-v+10 v^{0.5}\left[\mathrm{kcal} /\left(\mathrm{h} \cdot \mathrm{m}^{2} \cdot \mathrm{K}\right)\right]$, where $v[\mathrm{~m} / \mathrm{s}]$ is the air speed. The formula is valid for speeds between $2 \mathrm{~m} / \mathrm{s}$ and $20 \mathrm{~m} / \mathrm{s}$.

In Figure 3 we have the temperature distribution in case of forced convection with $\alpha=32.34 \mathrm{~W} /\left(\mathrm{m}^{2} \cdot \mathrm{K}\right)$, corresponding to the air speed $v=5 \mathrm{~m} / \mathrm{s}$. Values of $w_{0}, w_{S}$ and physical parameters are the same as in case of natural convection. b)

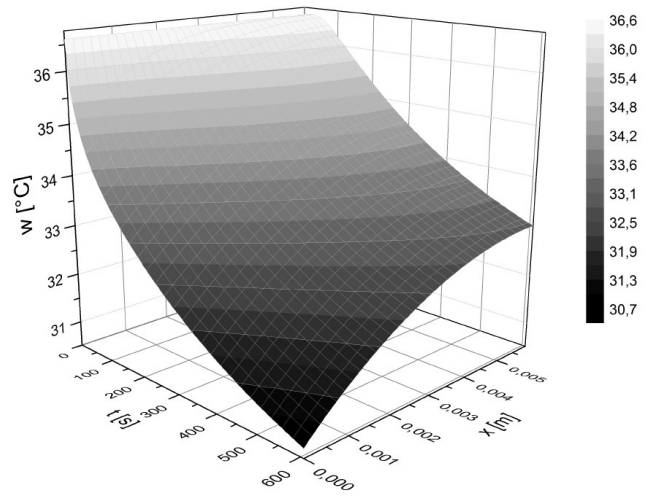

Fig. 2. Temperature distribution $\left[{ }^{\circ} \mathrm{C}\right]$ in case of natural convection with $\alpha=6.66 \mathrm{~W} /\left(\mathrm{m}^{2} \cdot \mathrm{K}\right)$ for a) selected values of time $t[\mathrm{~s}], \mathrm{b})$ for $t \in[0,665.2][\mathrm{s}]$ 
a)

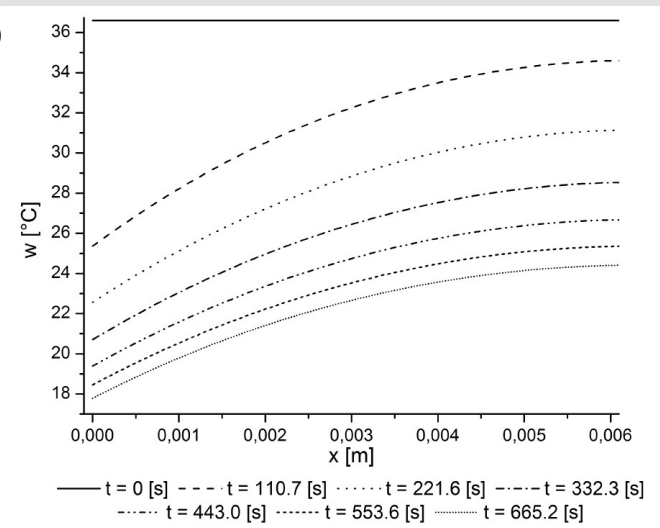

b)

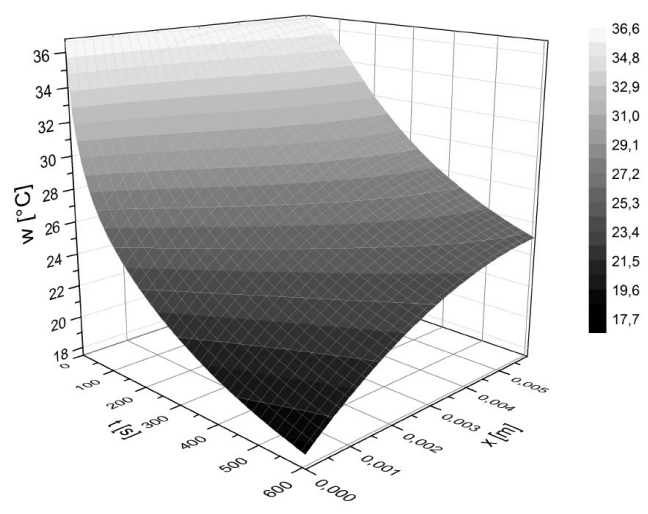

Fig. 3. Temperature distribution $\left[{ }^{\circ} \mathrm{C}\right]$ in case of forced convection with $\alpha=32.34 \mathrm{~W} /\left(\mathrm{m}^{2} \cdot \mathrm{K}\right)$ for a) selected values of time $t$ [s], b) for $t \in[0,665.2]$ [s]

\section{NUMERICAL EXPERIMENTS}

For the numerical computations we use the mean values of the parameters occurring in the problem formulation (see Tables 1-2). The exception is the blood perfusion rate $G_{\mathrm{B}}$ of dermis and subcutaneous tissue. We take $G_{B, 2}=G_{B, 3}=0.001251 / \mathrm{s}$. Furthermore, we assume the temperatures $w_{0}=309.75 \mathrm{~K}\left(36.6^{\circ} \mathrm{C}\right)$, $w_{S}=273.15 \mathrm{~K}\left(0^{\circ} \mathrm{C}\right)$ and we take the convection heat transfer coefficient $\alpha=6.66 \mathrm{~W} /\left(\mathrm{m}^{2} \cdot \mathrm{K}\right)$ for the natural convection, $\alpha=32.34 \mathrm{~W} /\left(\mathrm{m}^{2} \cdot \mathrm{K}\right)$ for the forced convection corresponding to the air speed $v=5 \mathrm{~m} / \mathrm{s}$. Interval values of parameters are also taken in relation to the mean values considered.

The initial-boundary value problem given in the non-dimensional form (11)-(13) with (14) is solved with different uncertainties of selected initial parameters. Subsequently, we use the interval method of Crank-Nicolson type (ICN-LHS method) with parameters represented by interval values and its conventional counterpart (CN-LHS method) with parameters equal to midpoints of such intervals. Interval values of selected parameters given in the dimensional and non- dimensional form are used with 10-bytes double extendedprecision format accuracy (Jankowska 2010). The temperature distribution in the form of interval solutions and approximate solutions corresponding to the time $\tau=1.5(t \cong 665.2 \mathrm{~s})$ is presented in the non-dimensional and dimensional coordinates. Subsequently, we denote the interval values of temperature with capital letters and the approximate values of temperature with small letters. Finally, we denote by $d$ widths of interval values of parameters and temperature.

\subsection{Case 1: natural convection}

We assume hypothetically that values of all input parameters are known exactly. Hence, we only have to deal with the representation errors, rounding errors and the error of the conventional method. Comparison of the widths of the interval solutions obtained for different values of stepsizes $h$ and $k$, lets us examine the efficiency of the ICN-LHS method (see Figs 4-7). We have the following interval values of the thickness of skin, the effective parameters and the non-dimensional parameters:

$$
\begin{array}{lll}
L \in[+6.28999999999999999 \mathrm{E}-03,+6.29000000000000001 \mathrm{E}-03], & d(L)=+1.2705 \mathrm{E}-21 \\
\lambda_{e f} \in[+2.59785373608903020 \mathrm{E}-01,+2.59785373608903021 \mathrm{E}-01], & d\left(\lambda_{e f}\right)=+1.8973 \mathrm{E}-19 \\
c_{e f} \in[+2.86669316375198728 \mathrm{E}+03,+2.86669316375198729 \mathrm{E}+03], & d\left(c_{e f}\right)=+1.3322 \mathrm{E}-15 \\
\rho_{e f} \in[+1.01574562798092209 \mathrm{E}+03,+1.01574562798092210 \mathrm{E}+03], & d\left(\rho_{e f}\right)=+5.5511 \mathrm{E}-16 \\
\kappa_{e f} \in[+8.92171864852069969 \mathrm{E}-08,+8.92171864852069972 \mathrm{E}-08], & d\left(\kappa_{e f}\right)=+1.6802 \mathrm{E}-25 \\
g_{1} \in[+7.49651025650836875 \mathrm{E}-01,+7.49651025650836880 \mathrm{E}-01], & d\left(g_{1}\right)=+3.5236 \mathrm{E}-18 \\
g_{2} \in[-7.48658616045867632 \mathrm{E}-01,-7.48658616045867627 \mathrm{E}-01], & d\left(g_{2}\right)=+3.4694 \mathrm{E}-18 \\
\mathrm{Bi} \in[+1.61253882072152014 \mathrm{E}-01,+1.61253882072152016 \mathrm{E}-01], & d(\mathrm{Bi})=+1.8973 \mathrm{E}-19
\end{array}
$$

a)

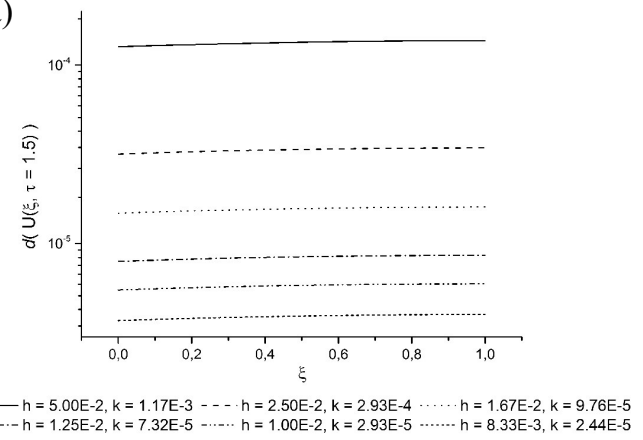

b)

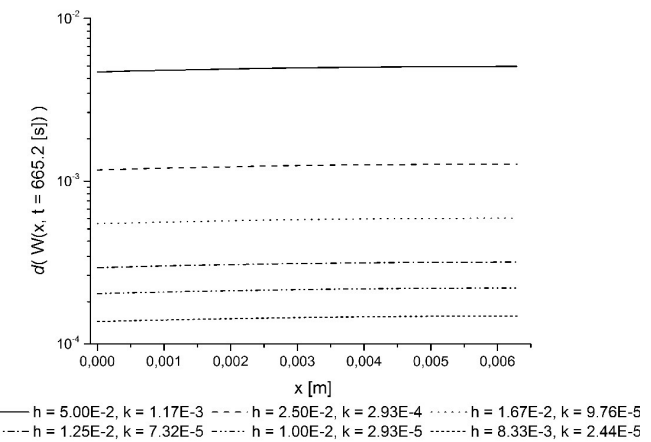

Fig. 4. Widths of the interval solutions a) $U(\xi, \tau=1.5)$; b) $W(x, t=665.2 \mathrm{~s})$ obtained with the ICN-LHS method for different values of stepsizes $h$ and $k$ 
a)

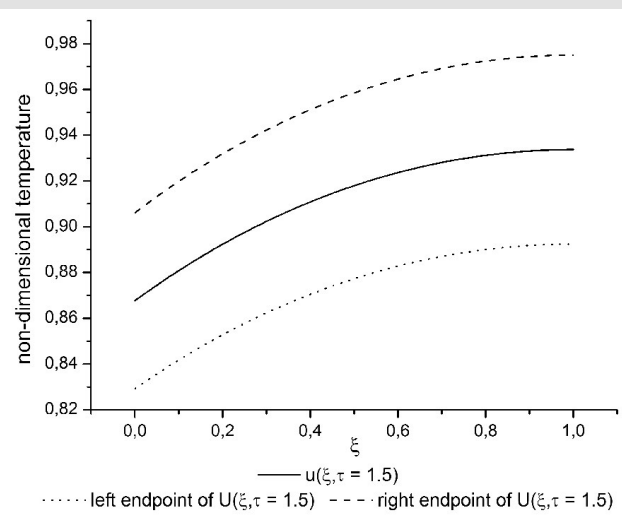

b)

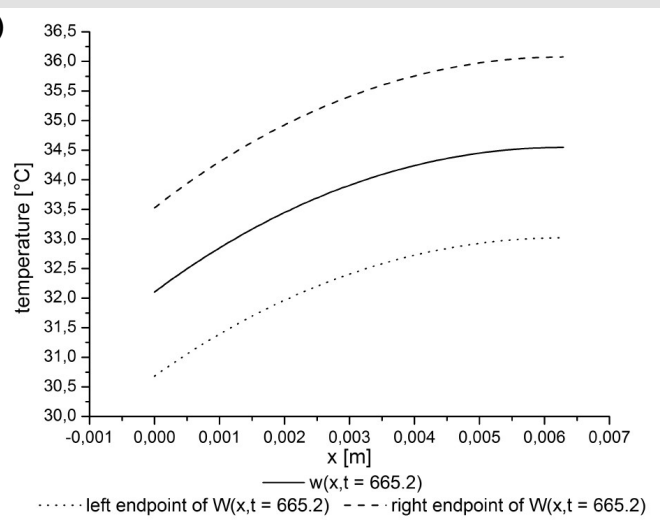

Fig. 5. The approximate and interval solutions, obtained with the CN-LHS and ICN-LHS methods for $h=1 \mathrm{E}-2, k \approx 2.93 \mathrm{E}-5$ in case of uncertainty about metabolic heat generation of dermis and subcutaneous tissue, given in the a) non-dimensional;

b) dimensional coordinates
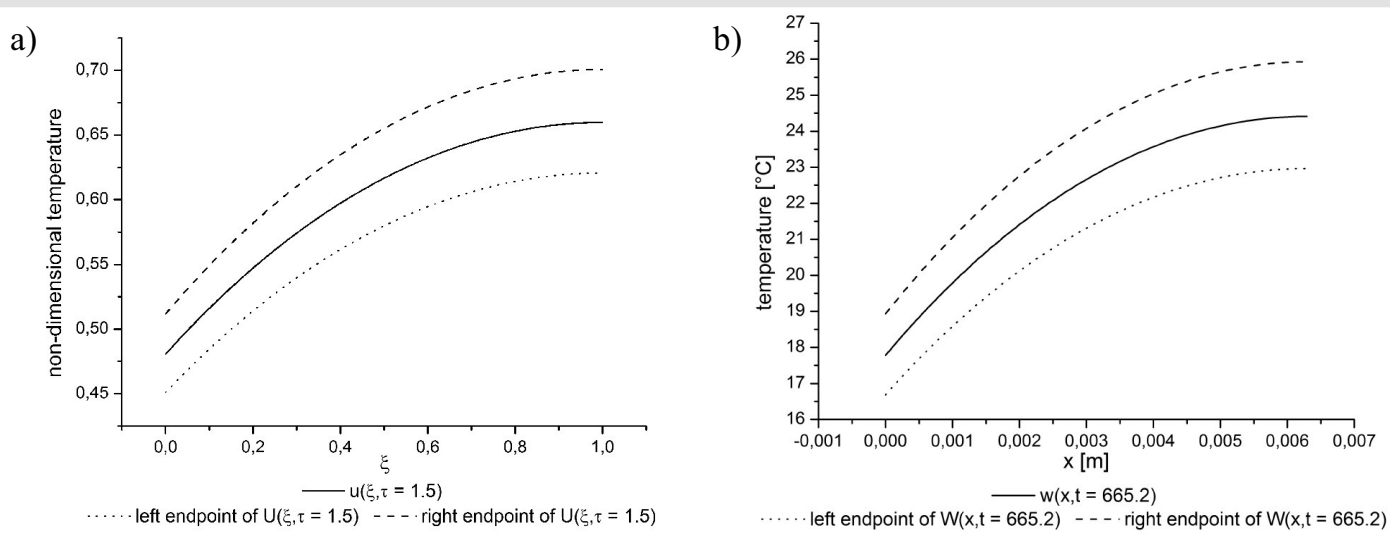

Fig. 6. The approximate and interval solutions, obtained with the CN-LHS and ICN-LHS methods for $h=1 \mathrm{E}-2, k \approx 2.93 \mathrm{E}-5$ in case of uncertainty about thickness of dermis, given in the a) non-dimensional; b) dimensional coordinates
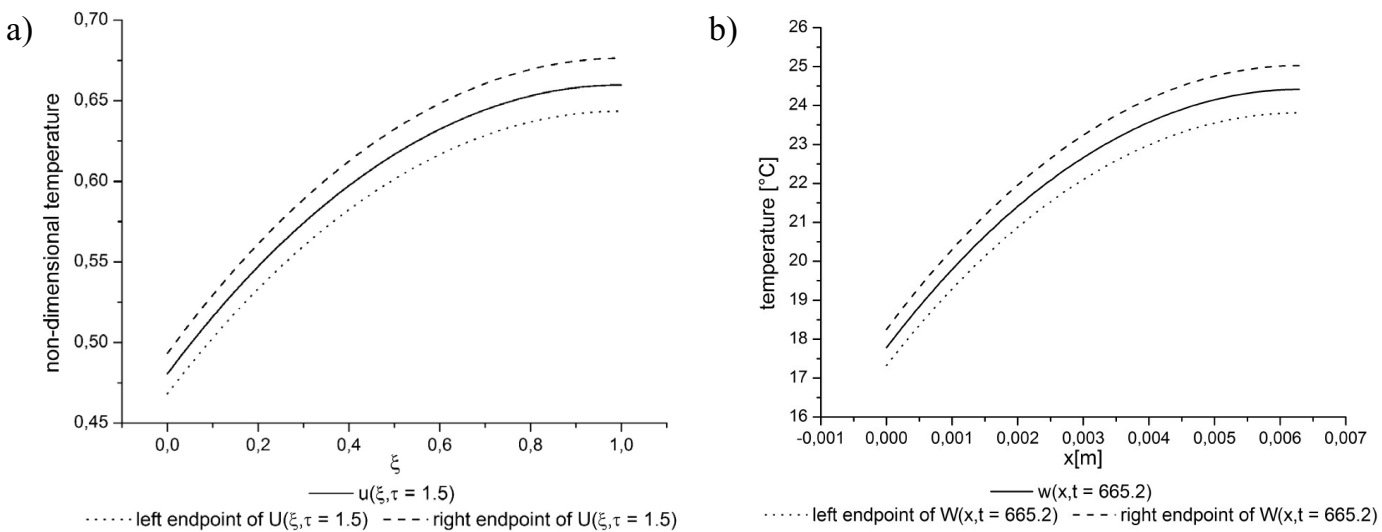

Fig. 7. The approximate and interval solutions, obtained with the CN-LHS and ICN-LHS methods for $h=1 \mathrm{E}-2, k \approx 2.93 \mathrm{E}-5$ in case of uncertainty about thermal conductivity, specific heat and mass density of dermis, given in the a) non-dimensional; b) dimensional coordinates

Now let us assume uncertainty about the metabolic heat generation of dermis and subcutaneous tissue such that it includes the state when the organism is in rest with $\dot{Q}_{m e t}=245 \mathrm{~W} / \mathrm{m}^{3}$ and in motion with $\dot{Q}_{m e t}=245 \cdot 10^{2} \mathrm{~W} / \mathrm{m}^{3}$ as well (Będziński 2011). We have

$$
\dot{Q}_{m e t, 2} \in[+245,+24500], \dot{Q}_{m e t, 3} \in[+245,+24500], d\left(\dot{Q}_{m e t, 2}\right)=d\left(\dot{Q}_{m e t, 3}\right)=+2.4255 \cdot 10^{4}
$$

and

$$
\begin{aligned}
& g_{1} \in[+7.49651025650836875 \mathrm{E}-01,+8.47899576542792451 \mathrm{E}-01], \\
& g_{2} \in[-7.48658616045867632 \mathrm{E}-01,-7.48658616045867627 \mathrm{E}-01], \\
& \mathrm{Bi} \in[+1.61253882072152014 \mathrm{E}-01,+1.61253882072152016 \mathrm{E}-01]
\end{aligned}
$$$$
d\left(g_{1}\right)=+9.8248 \mathrm{E}-02
$$$$
d\left(g_{2}\right)=+3.4694 \mathrm{E}-18
$$$$
d(\mathrm{Bi})=+1.8973 \mathrm{E}-19
$$ 
Jankowska M.A., 2013, The Error Term Approximation in Interval Method of Crank-Nicolson Type, Differential Equations and Dynamical Systems, 21 (1) 185-198.

Jankowska M.A., Marciniak A., An Interval Finite Difference Method for Solving the One-Dimensional Heat Conduction Equation, Lecture Notes in Computer Science (in print).

Jankowska M.A., Sypniewska-Kaminska G., Kaminski H., 2012, Evaluation of the Accuracy of the Solution to the Heat Conduction Problem with the Interval Method of Crank-Nicolson Type, Acta Mechanica et Automatica, 6(1), pp. 36-43.

Jankowska M.A., Sypniewska-Kamińska G., 2013, Interval Finite-Difference Method for Solving the One-Dimensional Heat Conduction Problem with Heat Sources, Lecture Notes in Computer Science, 7782, 473-488.

Kużelewski A., 2008, Opracowanie i implementacja algorytmu modelowania i symulacji nieprecyzyjnie zdefiniowanych zagadnień brzegowych, Ph.D. Thesis, Białystok.

Majchrzak E., Dziatkiewicz G., Paruch M., 2008, Acta of Bioengineering and Biomechanics, 10(2), pp. 29-37.

Majchrzak E., Jasiński M., 2003, Numerical estimation of burn degree of skin tissue using the sensitivity analysis methods, Acta of Bioengineering and Biomechanics, 5(1), pp. 93-108.

Majchrzak E., Mochnacki B., Dziewoński M., Jasiński M., Kałuża G., 2005, Modelowanie numeryczne przeplywu biociepla, Nauka, Innowacje, Technika, 2, 9, pp. 30-38.

Marciniak A., 2009, Selected Interval Methods for Solving the Initial Value Problem, Publishing House of Poznan University of Technology, Poznan.
Marciniak A., 2012, An interval version of the Crank-Nicolson methodThe first approach, Lecture Notes in Computer Science, 7133, pp. $120-126$

Moore R.E., 1966, Interval Analysis, Prentice-Hall, Englewood Cliffs, NJ.

Orzechowski Z., Prywer J., Zarzycki R., 2001, Mechanika plynów w inżynierii środowiska, WNT.

Piasecka-Belkhayat A., 2011, Przedzialowa metoda elementów brzegowych w nieprecyzyjnych zadaniach nieustalonej dyfuzji ciepla, Wydawnictwo Politechniki Śląskiej, Gliwice.

Pennes H.H., 1948, Analysis of Tissue and Arterial Blood Temperature in the Resting Human Forearm, Journal of Applied Physiology, 1, pp. 93-122.

Sunaga T., 1958, Theory of interval algebra and its application to numerical analysis, Research Association of Applied Geometry (RAAG), Vol. 2, Misc. II, pp. 547-564.

Szyszka B., 2012, The Central Difference Interval Method for Solving the Wave Equation, Lecture Notes in Computer Science, 7204, pp. 523-532.

Torvi D.A., Dale J.D., 1994, A finite element model of skin subjected to a flash fire, Journal of Biomechanical Engineering, 116, pp. 250-255.

Xu F., Seffen K.A., Lu T.J., 2008, Non-Fourier analysis of skin biothermomechanics, Interna-tional Journal of Heat and Mass Transfer, 51, pp. 2237-2259.

Zieniuk E., 2000, Nowa koncepcja rozwiqzywania rozmytych zagadnień brzegowych, Informatyka teoretyczna. Metody analizy informacji niekompletnej i rozproszonej, Politechnika Białostocka, X lat Instytutu Informatyki, Białystok, pp. 182-192. 